\title{
PERAN PEMERINTAH DESA DALAM MENGELOLA WISATA HUTAN PINUS UNTUK MENINGKATKAN PENDAPATAN ASLI DESA DI DESA BENDOSARI, KECAMATAN PUJON, KABUPATEN MALANG
}

\author{
Dewi Citra Larasati, Ya'taufiq Kurrahman \\ Program Studi Administrasi Publik Fakultas Ilmu Sosial dan Ilmu Politik \\ Universitas Tribhuwana Tunggadewi \\ Email: citralarasati311@gmail.com
}

\begin{abstract}
This study aimed to determine the role of the village government in managing pine forest tourism to increase the Village Original Revenue (PAD) in Bendosari Village, Pujon District, Malang Regency and identify the problems faced by the Bendosari Village Government. The study used a qualitative method with data collection technique using a combination of interviews, observation, and documentation triangulation. While the sampling technique used Puporsive Sampling. From this research, the results showed that the role of Bendosari village government were disseminating and planning the development of pine forest tourism areas, forming POKDARWIS, conducting tourism promotion on social media, and conducting comparative studies in other tourist villages. While the factors that influenced the implementation were the natural conditions that were affected during the rainy season and the human resources, such as the lack of awareness and ability of the community to manage the pine forest tourism. So there is a need for an intensive training and mentoring from the Bendosari village government.
\end{abstract}

Keyword: Village Government, Development, Tourism Village Management

\begin{abstract}
Abstrak: Penelitian ini bertujuan untuk mengetahui peran Pemerintah Desa dalam pengelolaan wisata hutan pinus dalam meningkatkan Pendapatan Asli Desa (PAD) di Desa Bendosari Kecamatan Pujon Kabupaten Malang dan mengidentifikasi permasalahan yang dihadapi oleh Pemerintah Desa Bendosari. Penelitian menggunakan metode kualitatif dengan tehnik pengumpulan data menggunakan triangulasi perpaduan antara wawancara, observasi, dan dokumentasi. Dengan teknik penentuan sampling menggunakan Puporsive Sampling. Dari penelitian ini diperoleh hasil Peran pemerintah Desa Bendosari, Kecamatan Pujon, Kabupaten Malang adalah melakukan sosialisasi dan perencanaan pembangunan kawasan wisata Hutan pinus, membentuk POKDARWIS, melakukan promosi pariwisata ke media sosial, dan melakukan studi banding ke desa wisata lainnya. Sedangkan faktor-faktor yang mempengaruhi pelaksanaan peran Pemerintah Desa dalam pengelolaan wisata hutan pinus adalah keadaan alamnya yang terpengaruh saat musim hujan dan keadaan sumber daya manusianya yaitu kurangnya kesadaran dan kemampuan masyarakat terhadap pengelolaan Wisata Hutan Pinus. Sehingga perlu adanya pelatihan dan pendampingan secara intensif dari Pemerintah Desa Bendosari.
\end{abstract}

Kata Kunci: Pemerintah Desa; Pembangunan; Pengelolaan Desa Wisata

\section{PENDAHULUAN}

Pembangunan sejatinya dapat membuka lapangan pekerjaan yang sangat luas sehingga bermunculan kesempatan kerja bagi masyarakat. Pembangunan sektor pariwisata adalah salah satu pembangunan yang giat dijalankan oleh pemerintah ditujukan pada pengembangan wisata sebagai sektor unggulan agar mampu menjadi salah satu penghasil 
devisa, mendorong ekonomi, meningkatkan pendapatan daerah, memberdayakan perekonomian rakyat, memperluas lapangan pekerjaan, dan kesempatan berusaha serta meningkatkan kesejahteraan rakyat dengan memilhara kepribadian bangsa, nilai-nilai agama serta kelestarian fungsi dan mutu lingkungan hidup. Salah satu prinsip kepariwisataan yang terkandung dalam undang-undang Nomor 10 tahun 2009 tentang kepariwisataan adalah memberdayakan masyarakat setempat dimana masyarakat berhak berperan dalam proses pembangunan kepariwisataan, berkewajiban menjaga kelestarian lingkungan destinasi pariwisata.

Sektor pariwisata adalah primadona untuk usaha pemberdayaan ekonomi kerakyatan dan memiliki efek yang sangat luas. Karena usaha-usaha di sektor pariwisata berpengaruh terhadap banyak sektor-sektor yang lain. Sehingga berdampak terhada kehidupan ekonomi masyarakat. Kebijakan pemerintah lokal dalam mengembangkan pariwisata sangat penting dalam menunjang keberhasilan pembangunan pariwisata nasional. Pengembangan pembangunan objek wisata akan mampu memberikan sumbangan yang sangat besar apabila dikelola secara profesional, karena dengan partisipasi daerah yang bersangkutan, pariwisata bisa memacu pertumbuhan kawasan sekitar objek wisata tersebut. Peraturan mengenai otonomi daerah memberikan kebebasan pada pemerintah daerah untuk mengelola pariwisatanya. Hal ini tertuang dalam Undang-Undang Nomor 23 tahun 2015 tentang pemerintahan daerah, pasal 12 ayat 3 menjelaskan bahwa pariwisata adalah salah satu urusan pemerintahan pilihan. Sehingga perencanaan pengembangan daerah wisata dapat dimulai dengan mengenali potensi wilayah yang akan dijadikan sebagai lokasi pengembangan kepariwisataan.

Pengembangan pariwisata di Indonesia semakin maju, hal ini ditunjukkan dengan semakin banyak bermunculan desa wisata di setiap daerah yang sudah terorganisir dengan baik dan sudah melakukan regenerasi. Banyak dari desa-desa wisata tersebut mengunakan internet dan website untuk menginformasikan keunikan-keunikan desanya. Bahkan dalam lima tahun terakhir ini, fenomena swafoto di objek-objek wisata semakin mempercepat dikenalnya suatu objek wisata oleh publik yang lebih luas. Seperti : Desa Sungai Nyalo di Painan, Desa Madobak di Mentawai, Desa Taman Sari di Banyuwangi, Desa Wisata Pujon Kidul di Malang, Desa Seigentung di Gunungkidul, Desa Ubud di Bali, Desa Waturaka di Ende, Desa Ponggok di Klaten, Desa Teluk Meranti di Riau dan Desa Bontagula di Bontang.

Pemerintah Kabupaten Malang adalah salah satu pemerintah daerah di Provinsi Jawa Timur yang fokus dalam pengembangan konsep Desa Wisata. Pengembangan konsep Desa Wisata dilakukan melalui Kelompok Sadar Wisata (Pokdarwis) Kabupaten Malang yang terus mengalami peningkatan.

Berdasar catatan Dinas Kebudayaan dan Pariwisata Kabupaten Malang, jumlah Pokdarwis yang tercatat mengalami peningkatan yang cukup signifikan pada lima tahun terakhir sejak tahun 2013hingga 2018 Pokdarwis yang awalnya hanya sejumlah 5 ( lima) pokdarwis menjadi 85 (delapan puluh lima) Pokdarwis. Beberapa contoh Desa Wisata yang sudah mulai berkembang dan menggeliatkan sektor pariwisata Kabupaten Malang adalah Desa Wisata Ngadas. Desa tersebut masuk dalam wilayah Taman Nasional Bromo Tengger Semeru, dan merupakan desa tertinggi di Pulau Jawa. Desa Poncokusumo yang terletak di kaki Gunung Semeru dan ada juga Desa Wisata Hutan Pinus di Desa Bendosari, Kecamatan Pujon.

Desa Bendosari Kecamatan Pujon memiliki potensi alam yang sangat indah namun tidak ditunjang dengan tingkat pendidikan penduduk yang ada disana. Berdasarkan dari data di website resmi Desa Bendosari menyebutkan bahwa dari 4179 penduduk desa sekitar 
$75,42 \%$ tingkat pendidikan penduduk masih sangat rendah tediri dari 47,86 \% penduduk tamatan SD/sederajat, $17,8 \%$, penduduk belum sekolah dan $9,76 \%$ belum tamat SD. Adanya permasalahan ini sehinggan penelitian ini bertujuan untuk 1) Untuk mengetahui peran pemerintah desa dalam pengelolaan wisata hutan pinus untuk meningkatkan PAD di Desa Bendosari Kecamatan Pujon Kabupaten Malang, dan 2) untuk mengidentifikasi faktor-faktor yang mempengaruhi pelaksanaan peran pemerintah desa dalam pengelolaan wisata hutan pinus untuk meningkatkan PAD di Desa Bendosari Kecamatan Pujon Kabupaten Malang.

Menurut Undang-Undang Republik Indonesia Nomor 6 Tahun 2014 tentang Desa, dijelaskan dalam Pasal 1 yang dimaksud dengan Pemerintahan Desa adalah penyelenggaraan urusan pemerintahan dan kepentingan masyarakat setempat dalam sistem pemerintahan Negara Kesatuan Republik Indonesia. Di Pasal 1 ayat 3, Pasal 23 sampai dengan Pasal 25 dijelaskan Pemerintahan Desa diselenggarakan oleh Pemerintah Desa yang mana Pemerintah Desa tersebut adalah seorang Kepala Desa atau sebutan lainnya sesuai dengan kekhasan daerahnya masing-masing. Kepala Desa tersebut dibantu oleh perangkat Desa sebagai unsur penyelenggara Pemerintahan Desa. Penyelenggaraan Pemerintahan Desa berdasarkan asas: kepastian hukum, tertib penyelenggaraan pemerintahan, tertib kepentingan umum, keterbukaan, proporsionalitas, profesionalitas, akuntabilitas, efektivitas dan efisiensi, kearifan lokal, keberagaman, dan partisipatif.

Menurut Soekanto dalam Buga dan Larasati (2018) peran adalah "Proses dinamis kedudukan (status). Jadi apabila seseorang melaksanakan hak dan kewajiban sesuai dengan kedudukannya, berarti dia menjalankan suatu peranan. Menurut Undang-Undang Republik Indonesia Nomor 6 Tahun 2014 tentang Desa Pasal 26 ayat 1 menyebutkan Kepala Desa bertugas menyelenggarakan Pemerintahan Desa, melaksanakan Pembangunan Desa, pembinaan kemasyarakatan Desa, dan pemberdayaan masyarakat Desa. Dalam menjalankan tugasnya tersebut, pasal 26 ayat 2 menjelaskan beberapa kewenangan Kepala Desa adalah sebagai berikut : a. memimpin penyelenggaraan Pemerintahan Desa; b. mengangkat dan memberhentikan perangkat Desa; c. memegang kekuasaan pengelolaan Keuangan dan Aset Desa; d. menetapkan Peraturan Desa; e. menetapkan Anggaran Pendapatan dan Belanja Desa; f. membina kehidupan masyarakat Desa; g. membina ketenteraman dan ketertiban masyarakat Desa; h membina dan meningkatkan perekonomian Desa serta mengintegrasikannya agar mencapai perekonomian skala produktif untuk sebesar-besarnya kemakmuran masyarakat Desa; i. mengembangkan sumber pendapatan Desa; j. mengusulkan dan menerima pelimpahan sebagian kekayaan negara guna meningkatkan kesejahteraan masyarakat Desa; k. mengembangkan kehidupan sosial budaya masyarakat Desa; 1. memanfaatkan teknologi tepat guna; m. mengoordinasikan Pembangunan Desa secara partisipatif; n. mewakili Desa di dalam dan di luar pengadilan atau menunjuk kuasa hukum untuk mewakilinya sesuai dengan ketentuan peraturan perundang-undangan; dan o. melaksanakan wewenang lain yang sesuai dengan ketentuan peraturan perundang-undangan.

Menurut Undang-Undang Republik Indonesia Nomor 6 Tahun 2014 tentang Desa Pasal 26 ayat 3 menjabarkan kewajiban dari Kepala Desa adalah sebagai berikut: a) memegang teguh dan mengamalkan Pancasila, melaksanakan Undang-Undang Dasar Negara Republik Indonesia Tahun 1945, serta mempertahankan dan memelihara keutuhan Negara Kesatuan Republik Indonesia, dan Bhinneka Tunggal Ika, b) meningkatkan kesejahteraan masyarakat Desa, c) memelihara ketenteraman dan ketertiban masyarakat Desa, d) menaati dan menegakkan peraturan perundangundangan, e) melaksanakan kehidupan demokrasi dan berkeadilan gender, f) melaksanakan prinsip tata Pemerintahan Desa yang akuntabel, 
transparan, profesional, efektif dan efisien, bersih, serta bebas dari kolusi, korupsi, dan nepotisme, g). menjalin kerja sama dan koordinasi dengan seluruh pemangku kepentingan di Desa, h) menyelenggarakan administrasi Pemerintahan Desa yang baik, i) mengelola Keuangan dan Aset Desa, j) melaksanakan urusan pemerintahan yang menjadi kewenangan Desa, k) menyelesaikan perselisihan masyarakat di Desa, l) mengembangkan perekonomian masyarakat Desa, m) membina dan melestarikan nilai sosial budaya masyarakat Desa, n) memberdayakan masyarakat dan lembaga kemasyarakatan di Desa, o) mengembangkan potensi sumber daya alam dan melestarikan lingkungan hidup, dan p) memberikan informasi kepada masyarakat Desa.

Sehubungan dengan pembangunan pariwisata yang melibatkan masyarakat, maka ada beberapa hal dalam pemberdayaan masyarakat yang perlu diperhatikan mengenai pembagian peran antara aparat pemerintah, peneliti, akademisi, swasta dan masyarakat serta Lembaga Swadaya Masyarakat (LSM) sebagai berikut:

Tabel 1. Pembagian Peran Penerima Manfaat Pemberdayaan Masyarakat

\begin{tabular}{|c|c|c|c|c|c|c|}
\hline $\begin{array}{c}\text { Ragam } \\
\text { kegiatan }\end{array}$ & $\begin{array}{c}\text { Aparat } \\
\text { Pemerintah }\end{array}$ & Peneliti & Akademisi & Swasta & Masyarakat & LSM \\
\hline Pencetus Ide & $\mathrm{v}$ & $\mathrm{v}$ & $\mathrm{v}$ & $\mathrm{v}$ & $\mathrm{v}$ & $\mathrm{v}$ \\
\hline $\begin{array}{c}\text { Pengambilan } \\
\text { keputusan }\end{array}$ & $\mathrm{v}$ & - & - & - & - & - \\
\hline $\begin{array}{c}\text { Penyedia } \\
\text { Input }\end{array}$ & $\mathrm{v}$ & - & - & $\mathrm{v}$ & - & - \\
\hline $\begin{array}{c}\text { Pelaksana } \\
\text { Kegiatan }\end{array}$ & - & - & - & $\mathrm{v}$ & $\mathrm{v}$ & - \\
\hline $\begin{array}{c}\text { Pemelihara } \\
\text { Hasil } \\
\text { Kegiatan }\end{array}$ & $\mathrm{v}$ & - & - & $\mathrm{v}$ & $\mathrm{v}$ & - \\
\hline $\begin{array}{c}\text { Pemantauan } \\
\text { dan Evaluasi }\end{array}$ & $\mathrm{v}$ & $\mathrm{v}$ & $\mathrm{v}$ & $\mathrm{v}$ & $\mathrm{v}$ & $\mathrm{v}$ \\
\hline
\end{tabular}

Sumber : Mardikanto dan Soebianto (2017:177)

Dalam menjalankan perannya seperti tabel diatas, Pemerintah Desa sebagai aparat pemerintah dihadapkan pada beberapa faktor-faktor yang mempengaruhi dalam pembangunan pariwisata berbasis Pemberdayaan Masyarakat yaitu sebagaimana berikut : 1) Keadaan sumber daya alam, 2) Keadaan sumber daya manusia, 3) kelembagaan untuk pembangunan, 4) sarana dan prasarana untuk pembangunan, 5) kebijakan pembangunan, 6) organisasi dan administrasi pemberdayaan masyarakat (Mardikanto dan Soebianto, 2017:188)

\section{METODE PENELITIAN}

Penelitian ini berangkat dari fenomena yang ada di masyarakat sehingga menggunakan pendekatan kualitatif. Lokasi penelitian untuk menggali data adalah Desa Bendosari, Kecamatan Pujon, Jalan M. Said Kretes Bendosari Pujon Kabupaten Malang. Penentuan informan dalam penelitian ini menggunakan metode purposive sampling, dengan informan yaitu Kepala Desa, Sekretaris Desa, Ketua Pengelola Wisata, Ketua Pokdarwis, dan Ketua RW. Teknik pengumpulan data melalui triangulasi memadukan observasi (pengamatan), interview (wawancara) dan dokumentasi. Instrumen penelitian yang digunakan adalah peneliti sendiri, panduan wawancara dan catatan lapangan. Teknik analisis data 
menggunakan data reduction (reduksi data), data display (penyajian data), dan conclusion drawing/verification (penarikan kesimpulan/verifikasi) serta keabsahan data menggunakan triangulasi sumber.

\section{HASIL DAN PEMBAHASAN}

Peran Pemerintah Desa dalam Pengelolaan Wisata Hutan Pinus untuk meningkatkan PAD di Desa Bendosari Kecamatan Pujon Kabupaten Malang.

Berdasarkan Undang-Undang yang mengatur mengenai Desa, Pemerintah Desa mempunyai kewajiban untuk memajukan derahnya dengan mengoptimalkan segala potensi dan kearifan lokal yag dimiliki. Salah satu upaya dari Pemerintah Desa Bendosari melalui Kepala Desa dan Perangkatnya adalah dengan melakukan pengelolaan wisata hutan pinus. Berikut ini adalah beberapa peran yang dilakukan oleh Pemerintah Desa Bendosari, sebagai berikut:

1) Pemerintah Desa Melakukan Sosialisasi Kepada Masyarakat Tentang Perencanaan Pembangunan Desa Wisata

Tingkat pendidikan penduduk yang masih rendah mempengarui tingkat pemahaman penduduk mengenai perencanaan pembangunan potensi wisata. Oleh karena itu Kepala Desa Bendosari mengupayakan berbagai cara untuk mendukung percepatan pembangunan kawasan desa wisata hutan pinus. Kepala Desa beserta perangkat desa lainnya mengadakan sosialisasi kepada masyarakat. Sosialisasi ini bertujuan untuk memberikan arahan dan pemahaman kepada masyarakat mengenai potensi wisata yang ada di Desa Bendosari. Potensi wisata ini bertujuan untuk meningkatkan perekonomian masyarakat, kesejahteraan masyarakat terjamin Apabila perekonomian masyarakat meningkat dan akan membawa dampak terhadap meningkatnya pendapatan asli desa. Oleh karena itu, setelah sosialisasi dilakukan, diharapkan masyarakat mengetahui mengenai potensi wisata di Desa Bendosari. Masyarakat harus ikut serta berperan aktif dalam pengelolaannya. Mulai dari perencanaan, penganggaran, pembangunan, pengelolaan hingga pengawasan.

2) Pemerintah Desa Proaktif Dalam Melakukan Perencanaan Pengembangan Kawasan Wisata Desa Hutan Pinus.

Setelah melakukan kegiatan sosialisasi dan mendapatkan dukungan dari masyarakat untuk mengembangkan kawasan desa wisata, Pemerintahan Desa selanjutnya membuat perencanaan dengan mempertimbangkan potensi yang ada dalam mengelola wisata hutan pinus. Pemerintah Desa berkewajiban untuk menjamin bahwa kepariwisataan dilaksanakan dapat memberikan manfaat untuk kesejahteraan rakyat, keadilan, kesetaraan, dan proporsionalitas memelihara kelesatarian alam dan lingkungan hidup. Pemerintah Desa juga telah memasukkan beberapa kegiatan ke dalam pembahasan Musyawarah Perencanaan Pembangunan Desa (MusrenbangDes) di Desa Bendosari. Masyarakat diajak untuk ikut musyawarah bersama-sama dengan pemerintah Desa untuk menggali potensi desa yang ada. Dengan dimasukkannya pengembangan kawasan wisata hutan pinus ke dalam pembahasan Musrenbang, pengembangan kawasan wisata desa ini menjadi terintegrasi, seperti pembangunan sarana dan prasarananya, pengelolaannya, serta pemberdayaan masyarakat melalui pembinaan kelompok sadar wisata (POKDARWIS).

\section{3) Membentuk Kelompok Sadar Wisata (POKDARWIS)}

Di bentuknya POKDARWIS ini agar masyarakat sadar akan pengelolaan wisata alam di daerahnya. Dengan melakukan kerjasama pemerintah desa dan masyarakat akan lebih mudah dalam percepatan pembangunan dan pengintegrasian pengelolaan kawasan wisata 
hutan pinus. Seperti pembangunan sarana dan prasarana di lokasi desa wisata (jalan menuju lokasi wisata, pembuatan tempat peristirahatan, pembangunan spot spot Selfie yang instagramable, mempromosikan kopi hutan pinus dengan pengelolaan yang sudah dikemas dengan menarik, dan masih banyak lagi lainnya). Selain itu, dengan adanya POKDARWIS, sangat berperan dalam membantu dalam mempromosikan wisata hutan pinus. Hal ini dikarenakan POKDARWIS merupakan fasilitator antara wisatawan yang berkunjung dan masyarakat petani, peternak, pemilik homestay yang merupakan tujuan wisata.

4) Mempromosikan Desa Wisata Bekerjasama Dengan Asosiasi Desa Wisata (ASIDEWI),

Dalam mempromosikan wisata di Desa Bendosari, Pemerintah Desa melakukan pembuatan banner, pamflet, dan membuat petunjuk arah untuk menuju ke tempat wisata, pemerintah juga bekerja sama dengan asosiasi desa wisata (ASIDEWI) dalam mempromosikan wisata juga melalui sosial media seperti facebook, instagram, twitter, dan melalui blog.

5) Melakukan Studi Banding Ke Desa Wisata Lain

Pemerintah Desa juga melakukan studi banding ke Desa wisata lain untuk menambah pengetahuan dalam pengelolaan dalam hal promosi desa wisata kemudian dapat mereplikasi strateginya jika hal itu sesuai dengan situasi dan kondisi Desa wisata.

Berdasarkan dari kelima hal yang telah dilakukan, Pemerintah Desa Bendosari telah menjalankan tugasnya sesuai dengan yang diamanatkan dalam Undang-Undang Republik Indonesia Nomor 6 Tahun 2014 tentang Desa. Pemerintah Desa berperan langsung dalam pencetus ide dengan memperhatikan keunggulan alamnya yang sangat indah sehingga potensi wisata bisa dikembangkan dengan baik di desa ini. Peran sebagai pengambil keputusan juga dilaksanakan, hal ini dengan melakukan perencanaan yang langsung dimasukkan dalam pembahasan Musrenbang Desa. Peran Penyedia Input juga ditunjukkan oleh Pemerintah Desa dengan memfasilitasi pembentukan Pokdarwis, pembangunan sarana-prasarana pendukung di Hutan Wisata Pinus seperti jalan menuju lokasi wisata, pembuatan tempat peristirahatan, pembangunan spot spot Selfie yang instagramable, serta mempromosikan kopi hutan pinus dengan pengelolaan yang sudah dikemas dengan menarik serta melakukan promosi denganberbagai macam media. Sehingga dalam pengelolaannya, yang melakukan adalah masyarakat langsung melalui Pokdarwis yang sudah dibentuk sebelumnya. Pemerintah Desa Bendosari juga melakukan peran pemeliharaan hasil kegiatan, pemantauan dan evaluasi. Hal ini dimaksudkan supaya pengelolaan Desa Wisata Hutan Pinus bisa terus berkelanjutan dan berkesinambungan sehingga pendapatan masyarakat lebih baik dan meningkatnya PAD Desa Bendosari.

Faktor-Faktor yang Mempengaruhi Pelaksanaan Peran Pemerintah Desa dalam Pengelolaan Wisata Hutan Pinus untuk Meningkatkan PAD di Desa Bendosari Kecamatan Pujon Kabupaten Malang.

Dalam menjalankan Perannya, Pemerintah Desa Bendosari menghadapi beberapa faktor-faktor yang berpengaruh dalam pengelolaan Objek Wisata Hutan Pinus sebagai berikut 1) Keadaan sumber daya alam, cuaca sangat berpengaruh dalam pengelolaan wisata hutan pinus ini. Apabila memasuki musim penghujan maka ini akan menjadi faktor penghambat, namun dengan hal ini pemerintah dengan cepat mengambil tindakan seperti membangunkan 
sarana peristirahatan untuk berteduh. Selain itu, karena geografis Desa Bendosari adalah perbukitan maka wilayah ini sangat rawan terkena bencana alam. 2) Keadaan sumber daya manusia, kurangnya kesadaran dan kemampuan masyarakat terhadap pengelolaan Wisata Hutan Pinus, hal ini dikarenakan tingkat pendidikan warganya masih rendah, sehingga Pemerintah Desa harus selalu berperan aktif mendampingi dan memberikan saran kepada POKDARWIS agar pengelolaan kawasan wisata hutan pinus ini terus berjalan dan muncul inovasi-inovasi sehingga menjadi lebih terkenal. Perlu adanya pelatihan dan pendampingan secara intensif mengingat tingkat pendidikan penduduk yang tergolong masih rendah dan pengalaman POKDARWIS yang masih sangat minim.

\section{KESIMPULAN}

Peran pemerintah Desa Bendosari, Kecamatan Pujon, Kabupaten Malang adalah melakukan sosialisasi dan perencanaan pembangunan kawasan wisata Hutan pinus, membentuk POKDARWIS, melakukan promosi pariwisata ke media sosial, dan melakukan studi banding ke desa wisata lainnya. Sedangkan faktor-faktor yang mempengaruhi pelaksanaan peran Pemerintah Desa dalam pengelolaan wisata hutan pinus adalah keadaan alamnya yang terpengaruh saat musim hujan dan keadaan sumber daya manusianya yaitu kurangnya kesadaran dan kemampuan masyarakat terhadap pengelolaan Wisata Hutan Pinus. Sehingga perlu adanya pelatihan dan pendampingan secara intensif dari Pemerintah Desa Bendosari.

\section{DAFTAR PUSTAKA}

Buga, Kresensia Egi dan Dewi Citra Larasati. 2018. Peran Badan Pelayanan Pajak Daerah Kota Malang dalam Mengurai Tunggakan PBB Perkotaan Hasil Pelimpahan dari Pemerintah Pusat. JISIP Volume 7 Nomer 3. Dikutip dari: https://publikasi.unitri.ac.id/index.php/fisip/article/view/1409

Larasati, D. (2019). Partisipasi Masyarakat dalam Mengembangkan Taman Posyandu Sri Rejeki Di Kelurahan Kotalama Kecamatan Kedungkandang. REFORMASI, 9 (1), 5565. doi:http://dx.doi.org/10.33366/rfr.v9i1.1323

Mardikanto, Totok dan Poerwoko Subianto. 2017. Pemberdayaan Masyarakat dalam Perspektif Kebijakan Publik. Bandung: Alfabeta.

Moleong, J. Lexi. 2014. Metode Penelitian Kualitatif. Bandung : PT. Remaja Rostadarya.

Peraturan Daerah (PERDA) Nomor 1 Tahun 2013 tentang Penyelenggaraan Kepariwisataan.

Solekhan, 2014, Penyelenggaraan Pemerintah Desa Berbasis Masyarakat, Malang : Stara Press Sugiyono. 2016. Metode Penelitian Kualitatif dan Kuantitaif. Bandung : Alfabeta.

Undang-Undang Republik Indonesia Nomor 6 Tahun 2009 tentang Desa

Undang-Undang Republik Indonesia Nomor 10 Tahun 2009 tentang Kepariwisataan dengan Rencana Induk Pengembangan Kepariwisataan di Tingkat Provinsi ataupun Kabupaten/Kota. 